\title{
Koncepcje ksztaltowania zrównoważonego środowiska mieszkaniowego na rewitalizowanych postindustrialnych terenach miejskich
}

\author{
Beata Majerska-Pałubicka \\ Katedra Projektowania Architektury Mieszkaniowej i Użyteczności Publicznej, \\ Wydział Architektury, Politechnika Śląska, e-mail: b.majerska-palubicka@polsl.pl
}

Streszczenie: Paradygmat zrównoważonego rozwoju oddziałując na wszystkie dziedziny życia obecny jest również w projektowaniu architektonicznym. W tym przypadku oznacza tworzenie dobrej przestrzeni do życia i relacji społecznych w sposób, który spełnia oczekiwania i daje szansę realizacji potrzeb zarówno obecnym, jak i kolejnym pokoleniom w długim przedziale czasu. Potrzeba zapewnienia dostępnego i przyjaznego środowiska, wpisującego się pełną infrastrukturą w kontekst otoczenia staje się priorytetem. W wielu krajach wypracowano strategie kreowania architektury i urbanistyki w granicach aglomeracji miejskich, które w udany sposób wpływają na integrację paradygmatu zrównoważonego rozwoju z kontekstem ekonomicznym, społecznym i przyrodniczym.

Analizowany obszar badawczy obejmuje koncepcje kształtowania środowiska mieszkaniowego na rewitalizowanych postindustrialnych terenach oraz peryferyjnie położonych, niezagospodarowanych dotąd obszarach miast.

Jako studium przypadku przeanalizowano przykłady dzielnic Ørestad, Sluseholmen i Teglværkshavnen w Kopenhadze, Eriksberg w Göteborgu, Vasta Hammen „City of Tomorrow” z kwartałem B01 w Malmö, Fjord City Bjorvike, Tjuvholmen i Sørenga w Oslo.

Jako metodę badań przyjęto systemowe podejście do tematu, oparte na badaniach i studiach empirycznych konkretnych przypadków, poszerzone o badania literaturowe oraz doświadczenia własne (projektowe i dydaktyczne) autorki.

Zamierzony rezultat badań to próba wskazania holistycznego podejścia i podstawowych narzędzi uwzględniających interesy wszystkich uczestników procesów kształtowania środowiska mieszkaniowego, prowadzących do sprecyzowania zrównoważonych strategii projektowych oraz krótko- i długoterminowych działań.

Słowa kluczowe: rewitalizacja, zrównoważona architektura, zrównoważone strategie projektowe.

\section{Wprowadzenie}

Potrzeba zapewnienia dostępnego i przyjaznego środowiska, wpisującego się pełną infrastrukturą w kontekst otoczenia wiąże się z zapisem preambuły konferencji Środowisko i Rozwój, która brzmi: „Istoty ludzkie stanowią centrum zainteresowania w procesie trwałego i zrównoważonego rozwoju. Mają prawo do zdrowego oraz twórczego życia w harmonii z przyrodą". [1] Środowisko mieszkaniowe, zapewniając miejsce schronienia i odpoczynku, przyczyniając się do tworzenia wzorców kulturowych, znajduje się w grupie podstawowych potrzeb człowieka. Z jednej strony, środowisko mieszkaniowe będąc efektem ingerencji 
w środowisko przyrodnicze a zarazem źródłem odpadów i zanieczyszczeń stanowi zagrożenie dla trwałego (zrównoważonego) rozwoju. Z drugiej strony, w sektorze budowlanym (realizującym środowisko mieszkaniowe) w kontekście paradygmatu zrównoważonego rozwoju kryje się ogromny potencjał, który niesie nowe wartości związane z osadzeniem środowiska naturalnego $\mathrm{w}$ roli podmiotu. Zrównoważone środowisko (przyrodnicze + zbudowane) $=$ wysoka jakość życia.

Zagadnienie wieloaspektowości architektury w kontekście zrównoważonego rozwoju determinuje dyskusje dotyczące poszukiwania sposobów zrównoważenia pomiędzy odbiorcą, zagadnieniami ekonomicznymi i środowiskowymi oraz wartościami twórczymi.

Jawi się jedno z najtrudniejszych pytań dotyczących architektury XXI wieku: Jak kształtować środowisko zbudowane w równowadze z naturą, nie zmniejszając osiągniętego poziomu rozwoju gospodarczego, społecznego i komfortu życia, przy zachowaniu wartości twórczych? [2]

Rozwiązaniem wydaje się być (oparte na definicji zrównoważonego rozwoju) tworzenie dobrej przestrzeni do życia w sposób, który spełnia oczekiwania i daje szansę realizacji potrzeb zarówno obecnym, jak i kolejnym pokoleniom w długim przedziale czasu.

\section{Rewitalizacja postindustrialnych terenów miejskich}

W wyniku przemian zachodzących w gospodarce, ekonomii i życiu społecznym obszary przemysłowe, które nierzadko były kolebką powstawania miast, tracą swoje znaczenie w ich strukturze. Zatem dla podniesienia prestiżu miast, przeciwstawieniu się degradacji dzielnic i rozlewaniu zabudowy na tereny niezainwestowane, tworzona jest nowa kompleksowa polityka rozwoju miast o szerokim zasięgu obejmującym zagadnienia poprawy jakości życia (mieszkanie i praca), zapewnienia trwałej ochrony środowiska przyrodniczego i kulturowego, ładu przestrzennego i estetyki krajobrazu miejskiego, budująca miedzy innymi poczucie tożsamości lokalnej. [3]

Nowe plany zagospodarowania przestrzennego w wielu miastach położonych u ujścia rzek lub bezpośrednio nad morzem, wykorzystują zdegradowane tereny portowe i stoczniowe na funkcje mieszkaniowe i przestrzenie publiczne uzupełnione bogatą ofertą zróżnicowanych usług, tworząc obszary atrakcyjne dla mieszkańców, inwestorów i turystów.

Ważnymi europejskimi przykładami rewitalizacji terenów portowych są Rotterdam, Doki Londynu, Hamburg, Düsseldorf, a też skandynawskie miasta portowe.

\section{Dobre praktyki - studium przypadku}

Architektura zrównoważona, oddziałująca w długim przedziale czasu potrzebuje rozwiązań racjonalnych i ponadczasowych, które podkreślają cechy miejsca. W krajach skandynawskich wypracowano strategie zrównoważonego rozwoju w rewitalizacji terenów nieużytkowanych i postindustrialnych, które w udany sposób wpływają na integrację w obszarach społecznym, przyrodniczym i ekonomicznym. Istotnym elementem tych strategii jest korzystny bezpośredni wpływ na jakość życia i realizację_potrzeb użytkowników (obecnych i przyszłych).

Analizowany obszar badawczy stanowiący dzielnice Ørestad, Sluseholmen i Teglværkshavnen w Kopenhadze, Eriksberg w Göteborgu, Vasta Hammen „City of Tomorrow” z kwartałem B01 w Malmö, Fjord City Bjorvike, Tjuvholmen i Sørenga w Oslo, to nowe koncepcje kształtowania środowiska mieszkaniowego na rewitalizowanych postindustrialnych terenach 
portowych i przemysłowych, ale również nowe dzielnice które są wynikiem przekształceń w sposób nowatorski peryferyjnie położonych, niezagospodarowanych dotąd obszarów miast. Strategie stanowią przykład tworzenia nowego, proekologicznego wizerunku miast i przestrzeni o wysokiej jakości oraz troski o ochronę środowiska i podkreślanie walorów kulturowych i krajobrazowych. Założenia to: racjonalne gospodarowanie terenem, wysoka efektywność pod względem proekologicznym, komfort zamieszkiwania, ograniczenie przemieszczania się samochodami osobowymi na rzecz rozwoju komunikacji publicznej, rozwój gospodarczy.

Charakteryzują je zróżnicowane kształtowanie krajobrazu miejskiego od przestrzeni o otwartych osiach widokowych aż po intymne zielone „wyspy” wokół których zaprojektowano budynki mieszkalne tworzące kwartały zabudowy. (Rys. 1) Wewnątrz kwartałów zlokalizowane są duże dziedzińce - zielone oazy, w których mieszkańcy mogą organizować miejsca wspólnego pobytu i rekreacji. [4]

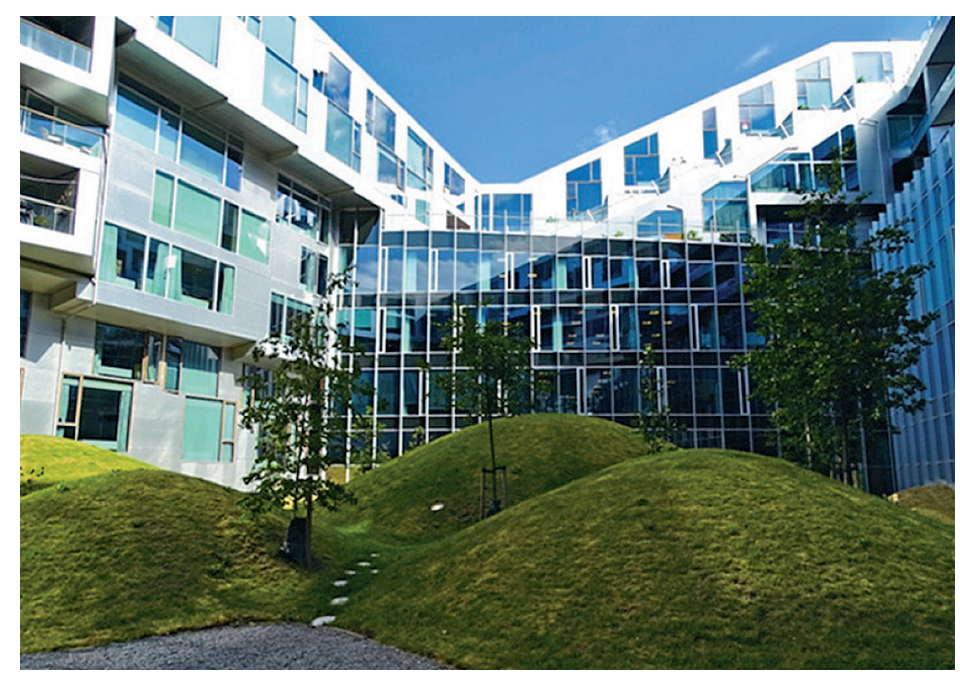

Rys. 1. 8 House Ørestad w Kopenhadze. arch. BIG Group [fot. autor]

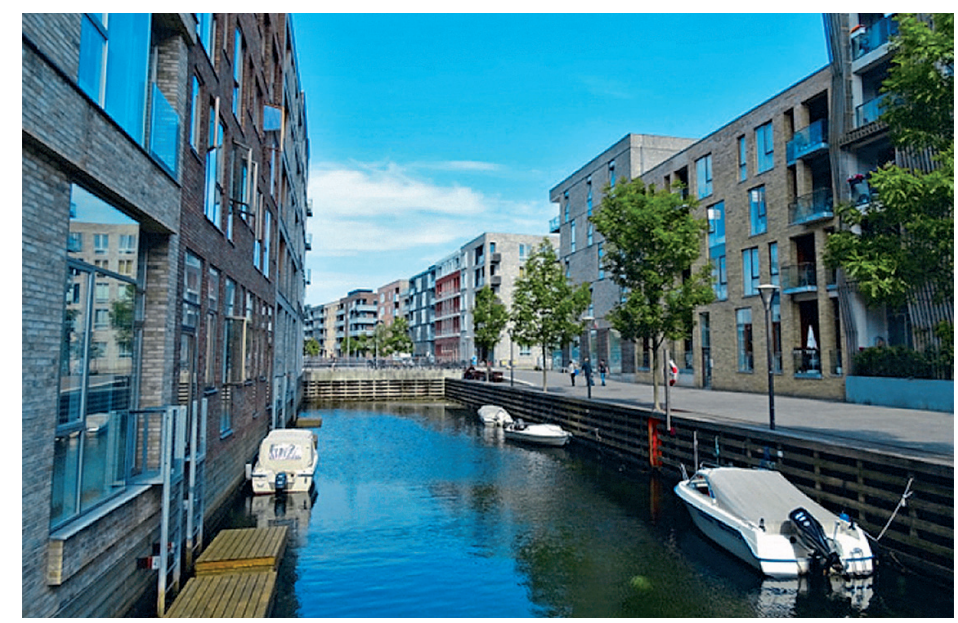

Rys. 2. South Harbour, Kopenhaga, arch. Arkitema [fot. autor] 


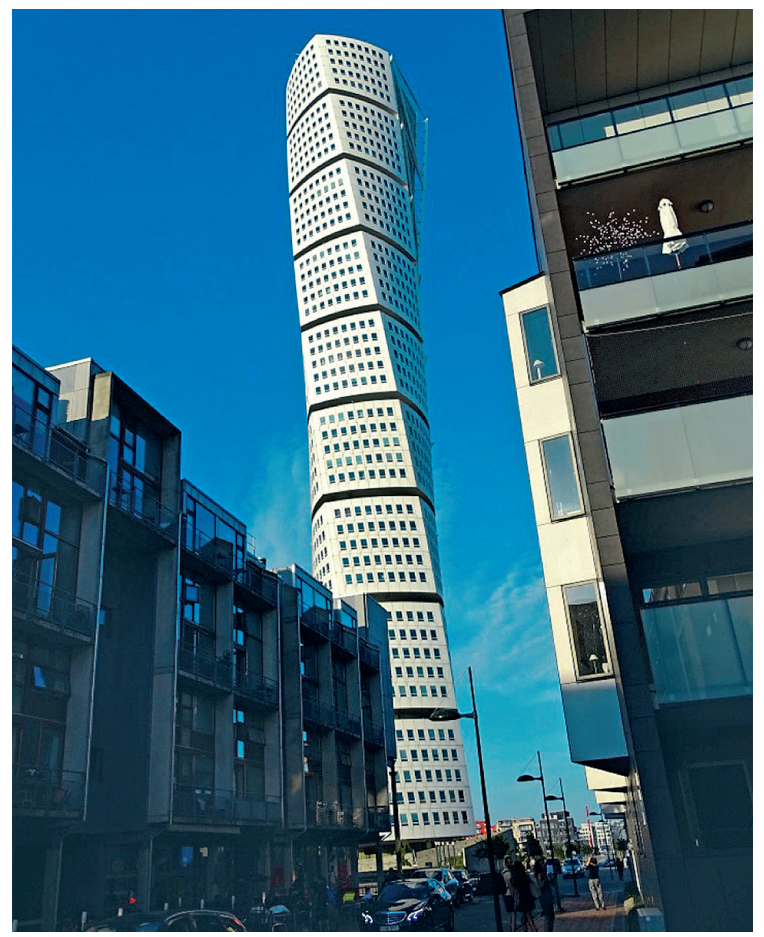

Rys. 3. Thurning Torso, Malmö, arch. S. Calatrava [fot. autor]

W wielu przypadkach woda odgrywa istotny element krajobrazu, domy stoją bezpośrednio nad kanałami i zbiornikami, a mosty i nabrzeża w formie traktów pieszych umożliwiają bezpośredni z nią kontakt (Rys. 2). [5]

$\mathrm{W}$ takim środowisku pojawiają się nowe elementy zagospodarowania terenu, w szczególności są nimi elementy związane ze zmianą priorytetów komunikacyjnych i segregacją odpadów.

Obiekty mieszkalne są programowo elastyczne i otwarte na indywidualne potrzeby współczesnego użytkownika stanowią przestrzenie bezpieczne i przyjazne dla użytkowników, umożliwiające życie rodzinne, realizację zainteresowań, kontakty społeczne i inne aktywności. Nie są pozbawione elementów twórczych, przykładów osobliwej i niezwykle wyrafinowanej architektury. Dbałość o każdy element, zróżnicowanie zabudowy tworzą atrakcyjne przestrzenie miejskie.

Rewitalizowane tereny portowe, zazwyczaj korzystnie zlokalizowane w tkance miast pod względem centralnego położenia i dostępności, stanowią doskonałe tereny inwestycyjne. Dla podniesienia ich atrakcyjności lokalizuje się w ich obszarze obiekty stanowiące ikony współczesnej architektury (Rys. 3).

\section{Wnioski}

Kreowanie komfortowego środowiska mieszkaniowego wymaga rzetelnej analizy pod względem ilościowym oraz jakościowym. Jak wynika z badań, w kreowaniu zrównoważonego środowiska mieszkaniowego powinien zaistnieć łańcuch powiazań prowadzący do 
racjonalizacji rozwiązań architektonicznych i urbanistycznych z uwzględnieniem aspektów: społecznego (obejmującego kontekst kulturowy i zaspokojenie potrzeb zarówno jednostki, jak również społeczności), ekologicznego (dotyczącego ochrony środowiska przyrodniczego i racjonalnego gospodarowania zasobami), ekonomicznego (dotyczącego rentowności inwestycji, modeli bussinesowych, dostosowania standardów i kosztów projektowanych obiektów do poziomu istniejącej gospodarki). Jakość struktury środowiska zależy od jego zróżnicowania społecznego i funkcjonalnego, od dobrze zdefiniowanych wnętrz urbanistycznych i przestrzeni publicznych, półpublicznych i prywatnych (dostępnych, bezpiecznych, estetycznych), które organizują życie lokalnych społeczności. Istotne znaczenie mają również tereny biologicznie czynne, zieleń i woda oddziałujące na walory estetyczne, rekreację i mikroklimat. Z tego względu bardzo istotne jest zachowanie właściwych proporcji pomiędzy obszarami zabudowy a terenami biologicznie czynnymi, (szczególnie na obszarach metropolitalnych, o wysokiej intensywności zabudowy i gęstości zaludnienia). W związku z tym założenie harmonii pomiędzy środowiskiem zbudowanym, gospodarką, społeczeństwem, systemami technologicznymi i środowiskiem przyrodniczym powinno leżeć u podstaw wszelkich działań podejmowanych na polu projektowania, realizacji, eksploatacji i rewitalizacji terenów, dając podstawę do podjęcia próby utworzenia koncepcji współczesnego środowiska mieszkaniowego.

Koncepcje nowego wykorzystania obszarów zajmowanych wcześniej przez porty sprawiły że realizacja projektów rewitalizacyjnych obecnie staje się symbolem wielkich zmian w kształtowaniu przestrzeni miejskich.

\title{
Literatura
}

[1] Dokumenty końcowe z Konferencji Organizacji ONZ „Środowisko i Rozwój” - „Szczyt Ziemi” w Rio de Janeiro w 1992 r., Instytut Ochrony Środowiska, Warszawa, 1993.

[2] Majerska-Pałubicka B. Zintegrowane projektowanie architektoniczne w kontekście zrównoważonego rozwoju. Doskonalenie procesu. Wyd. Pol. Śl., Gliwice, 2014.

[3] Gronostajska B. Rewitalizacja terenów portowych w Dusseldorfie nową marką miasta, Renowacje 2013, Przegląd Budowlany 3/2013.

[4] Majerska B. Ecological aspects in current housing. Proc. $9^{\text {th }}$ Architecture in Perspective 2017, VSBT Univerzita Ostrawa, 2017.

[5] http://srodmiesciemorskie.pl (29.11.2017).

\section{Concepts for designing a sustainable housing environment on revitalized post-industrial areas in cities}

\author{
Beata Majerska-Pałubicka \\ Department of Housing and Public Architecture Design, Faculty of Architecture, \\ Silesian University of Technology, e-mail: b.majerska-palubicka@polsl.pl
}

Abstract: The paradigm of sustainable development concerns social life in general.
In the architectural context this simply means creating a good space for living in a way that 
meets the expectations and gives a chance for the fulfilment of needs of both the current and future generations over a long period of time. The need to ensure an accessible and userfriendly environment whose infrastructure fits into the surroundings becomes a priority. In many countries, strategies have been developed in the field of architecture and urban planning within the limits of urban agglomeration, which in a successful way affect the integration of the sustainable development paradigm in the context of economic, social and natural sciences.

The analyzed research area includes new concepts of the development of housing environment in regenerated post-industrial areas as well as in new urban districts which result from innovative transformations of the previously undeveloped areas.

As a case study, the districts Vasta Hammen in Malmö, Fjord City Tjuvholmen and Sørenga in Oslo and Ørestad, Sluseholmen and Teglværkshavnen in Copenhagen, Eriksberg in Gothenburg were analyzed.

As a research method, a systematic approach to the topic was adopted, based on research and empirical studies of specific cases, expanded by literature research and own (design and didactic) experiments of the author.

The intended result of the research is an attempt to indicate a holistic approach and basic tools taking into account the interests of all participants in the processes of shaping the housing environment, leading to the specification of sustainable design strategies and shortand long-term actions.

Keywords: Revitalization, sustainable architecture, housing environment, sustainable design strategies. 